\title{
Pedagogia do oprimido: documento da reforma agrária no Chile
}

Joana Salém Vasconcelos

Professora de História Contemporânea na Faculdade Cásper Líbero. Doutora em História Econômica pela USP e mestra em Desenvolvimento Econômico pela Unicamp. Editora da Latin American Perspectives. Pesquisa com Bolsa Fapesp (2016/13432-4).

E-mail: joana.salem@gmail.com

Resumo: Esse artigo busca demonstrar que a Pedagogia do oprimido é um documento histórico da práxis de Paulo Freire na reforma agrária no Chile, lastreado na alfabetização camponesa durante seu exílio no país (1964-1969). Freire não apenas visitou assentamentos da reforma agrária, dialogou com trabalhadores rurais e formou milhares de alfabetizadores chilenos, como também produziu uma leitura política própria sobre a reforma agrária. Ao examinar as mudanças na estrutura de propriedades, o educador analisou as dinâmicas pelas quais se rompiam as hierarquias de poder e produção no campo, bem como a potência da alfabetização para desestabilizar velhas cadeias de comando. Assim, confirmou no Chile algumas hipóteses formuladas antes do golpe de 1964 no Brasil, como a "aderência ao opressor", a "cultura do silêncio" e a tensão entre diálogo e anti-diálogo.

Palavras-chave: Paulo Freire; Pedagogia do oprimido; Chile; reforma agrária.
Abstract: This article aims to demonstrate that the Pedagogy of the Oppressed is a historical document of the praxis of Paulo Freire within the agrarian reform in Chile, arising from peasant literacy policies during his exile in the country (1964-1969). Not only did Freire visited agrarian reform asentamientos, dialogued with rural workers, and trained thousands of Chilean literacy teachers, but he also produced his own political comprehension on the peasant's movement. Examining the changes in landownership structure, Freire analyzed how hierarchies of power and production in the countryside were broken, as well as the power of literacy in destabilizing old chains of command. Thus, the author confirmed in the Chilean context some hypotheses formulated before the 1964 military coup in Brazil, such as "adherence to the oppressor," the "culture of silence" and the tension between dialogue and anti-dialogue.

Keywords: Paulo Freire; Pedagogy of the Oppressed; Chile; agrarian reform. 


\section{comunicação \& educação • Ano XXVI • número 2 • jul/dez 2021}

1. FREIRE, Paulo. Pedagogia do oprimido. 65. ed Rio de Janeiro: Paz e Terra, 2018 , p. 45

2. FREIRE, Paulo. Pedagogia da esperança: um reencontro com a pedagogia do oprimido. 17. ed. Rio de Janeiro: Paz e Terra, 2011, p. 57-58.

3. Pedagogia do oprimido foi publicado pela primeira vez em 1968, em espanhol, pela editora Siglo Veintiuno (Buenos Aires); depois em 1970, em inglês, pela Herder and Herder (Nova York); e só em 1972, em português, pela editora portuguesa Afrontamento. No Brasil, foi lançado em 1974 pela editora Paz e Terra.

4. FREIRE, Paulo. Educação como prática da liberdade. Rio de Janeiro: Paz e Terra, 1967a.

5. A nomenclatura foi criada por Waldemar Cortés Carabantes, diretor da Chefatura Extraordinária para Educação de Adultos do Ministério da Educação Pública do Chile. AUSTIN, Robert (org.). Diálogos sobre Estado y educación popular en Chile: de Frei a Frei (1964-1993). Santiago: CECATP, 2004.
Raros são os camponeses que, ao serem "promovidos" a capatazes, não se tornam mais duros e opressores de seus antigos companheiros do que o patrão mesmo ${ }^{1}$.

Os camponeses discutiam seu direito à terra, à liberdade de produzir, de criar, de viver decentemente, de ser. Defendiam o direito de serem respeitados como gente e como trabalhadores, criadores de riqueza, e exigiam seu direito ao acesso à cultura e ao saber. É neste sentido que se entrecruzam as condições histórico-sociais em que se pode gestar a pedagogia do oprimido².

\section{INTRODUÇÃO}

Pedagogia do oprimido consta entre os dez livros mais importantes do mundo no século XX, segundo a Associação Americana pelo Desenvolvimento dos Estudos Curriculares. A filosofia educacional de Paulo Freire exposta na obra se tornou uma referência canônica para teorias e práticas pedagógicas ao redor do planeta, embora a especificidade da experiência histórica que deu origem a tal filosofia não receba a mesma atenção. Neste artigo, parto da constatação de que a amplitude teórica de Pedagogia do oprimido extrapolou o contexto específico da sua elaboração, mesmo que a historicidade do livro ainda seja fator determinante para sua leitura. $\mathrm{O}$ objetivo deste artigo é historicizar a atividade pedagógica de Paulo Freire durante o período em que esteve exilado no Chile, escrevendo o livro em $1968^{3}$, o que possibilita compreender sua participação na reforma agrária chilena e mapear os rastros dessa experiência em sua obra.

Paulo Freire viveu exilado no Chile entre novembro de 1964 e janeiro de 1969. Em Santiago, trabalhou como consultor da Unesco em duas instituições da reforma agrária: no Instituto de Desenvolvimento Agropecuário (Indap), entre 1964 e 1967; e no Instituto para Capacitação e Investigação da Reforma Agrária (Icira), de 1967 a 1968. Freire ainda interagiu cotidianamente com trabalhadores da Corporação de Reforma Agrária (Cora), que adotaram seu método para alfabetizar camponeses nos assentamentos. Nesse período, o Chile era governado pelo presidente Eduardo Frei Montalva (1964-1970), do Partido da Democracia Cristã (PDC, ou apenas DC), cujo viés reformista, ainda que fosse patrocinado pela Aliança para o Progresso e pela United States Agency for International Development (Usaid), permitiu a Freire dar continuidade a experiências interrompidas pelo golpe civil-militar de 1964 no Brasil ${ }^{4}$. Em outras palavras, Freire encontrou no Chile a oportunidade de consolidar hipóteses político-pedagógicas construídas no Brasil, que ganharam escala e se multiplicaram em seu exílio.

A lei de reforma agrária (16.640/1967) e a lei de sindicalização camponesa (16.625/1967) foram as grandes marcas do governo de Eduardo Frei, que adotou oficialmente o método de alfabetização de Paulo Freire sob a nomenclatura de "método psicossocial" . Freire formou mais de 10 mil educadores e técnicos 
rurais chilenos para atuar em campo com seu método. Ao conduzir pedagogias na reforma agrária chilena, o brasileiro encontrou terreno fértil para sua proposta conscientizadora, em um contexto favorável às mudanças estruturais. Nesse cenário, prosseguiu suas investigações sobre o papel da alfabetização dos oprimidos na alteração das hierarquias sociais, a ruptura de relações verticais de poder/saber induzidas pela "alienação da ignorância", a importância da "cultura do silêncio" na dominação de classe e a "aderência ao opressor" como entrave popular às mudanças democráticas ${ }^{6}$.

Escrito no calor da experiência prática, Pedagogia do oprimido reflete a vivência de Freire em diversas realidades camponesas em plena transformação, além de expressar a elaboração coletiva de suas equipes de trabalho. Freire tinha uma personalidade aberta e dialógica, interagia e aprendia com as pessoas ao seu redor. Nesse sentido, como indica a intertextualidade do livro, Pedagogia do oprimido é fruto de uma interpretação coletiva sobre as relações entre mudanças culturais e econômicas na reforma agrária chilena. Em meados de 1968, companheiros de trabalho de Freire na reforma agrária romperam com a DC e fundaram o Movimento de Ação Popular Unitária (Mapu), partido que integrou a Unidade Popular (UP) e venceu as eleições com Salvador Allende em outubro de 1970. Após a partida de Freire para os Estados Unidos, no início de 1969, as "equipes freirianas" deram sequência ao projeto político da Pedagogia do oprimido, que expunha flagrantes divergências com setores verticalistas das esquerdas.

Analisada deste ponto de vista, Pedagogia do oprimido torna-se não apenas um documento histórico sobre a reforma agrária no Chile, mas também o marco de uma "corrente freiriana" de atuação política no país ${ }^{7}$. A experiência contextual da reforma agrária deixou fortes rastros e evidências na obra, entre os quais destacam-se os diálogos de Freire com os camponeses. Em última instância, proponho que os camponeses chilenos são os verdadeiros protagonistas da Pedagogia do oprimido. Entretanto, uma leitura sem historicidade, que separa a teoria das experiências contextuais, encobre tais evidências.

Como documento de memória, Freire retomou a historicidade chilena da Pedagogia do oprimido em um capítulo de Pedagogia da esperança ${ }^{8}$. Alguns pesquisadores que se debruçaram sobre a passagem de Freire pelo Chile enfocaram diferentes aspectos fundamentais da sua trajetória e do desenvolvimento da sua pedagogia decorrentes de tal experiência, sem, contudo, apontar a chave interpretativa da Pedagogia do oprimido como documento histórico da reforma agrária9.

Este artigo está dividido em cinco partes. Na primeira, contextualiza-se o ambiente político encontrado por Paulo Freire no Chile e explica-se, em linhas gerais, a lei de reforma agrária de 1967 e o papel da "capacitação camponesa" na definição das novas formas de propriedade e trabalho. Na segunda, examina-se a concepção de Paulo Freire sobre a reforma agrária, localizando Pedagogia do oprimido dentro do corpus documental que intitulei como "escritos chilenos" de Freire. Na terceira, realiza-se uma análise das vozes camponesas presentes em Pedagogia do oprimido e o material empírico articulado por Freire a partir de seus diálogos com os trabalhadores rurais. Na quarta, examina-se o
6. FREIRE, Paulo. ¿Extensión o comunicación? Santiago: ICIRA, 1969; FREIRE, Paulo. Pedagogia do... Op. cit., 2018.

7. VASCONCELOS, Joana Salém. "O lápis é mais pesado que a enxada": reforma agrária no Chile e pedagogias camponesas para transformação econômica (1955-1973). 2020b. Tese (Doutorado em História Econômica) - Universidade de São Paulo, São Paulo, 2020b.

8. FREIRE, Paulo. Pedagogia da... Op. cit., p. 71-113.

9. ARAVENA ALVARADO, Rodrigo; DÍAZ-DIEGO, José. Paulo Freire en Chile (1964-1969): testimonios de exdirigentes campesinos durante la reforma agraria. Informes Fondo de Apoyo a la Investigación Patrimonial, Santiago, n. 18, p. 91-118, 2016; AUSTIN, Robert. State, literacy \& popular education in Chile: 1964-1990. Lanham: Lexington Books, 2003; GAJARDO, Marcela. Paulo Freire: crónica de sus años en Chile. Santiago: Flacso Chile, 2019; HOLST, John. Paulo Freire in Chile, 1964-1969: "Pedagogy of the Oppressed" in its sociopolitical economic context. Harvard Educational Review Cambridge, v. 76 n. 2, p. 243 270, 2006; KIRKENDALL, Andrew. Paulo Freire and the Cold War politics of literacy. Chapel Hill: University of North Carolina Press, 2010; WILLIAMSON, Guillermo. Paulo Freire (1965-1969): su paso por Chile y el Chile por que pasó. Santiago, 1989. Mimeografado; ZUBICUETA LUCO, Daniela. De imágenes, palabras y diálogos: alfabetización freiriana y concientización campesina durante la reforma agraria en Chile (1965-1973). 2018. Tesis (Magíster en Historia) Universidad de Santiago de Chile, Santiago, 2018. E os testemunhos: AUSTIN, Robert. Diálogos... Op. cit.; FERNÁNDEZ, José Antonio. La construcción de un pensamiento inacabado. 


\section{comunicação \& educação • Ano XXVI • número 2 • jul/dez 2021}

Cuadernos de Pedagogía, Santiago, n. 265 p. 61-65, 1998; OSORIO VARGAS, Jorge (org.) Freire entre nos: a 50 años de Pedagogía del Oprimido. La Serena: Universidad de La Serena, 2018.

10. Para itinerários biográficos, ver: FREIRE, Paulo; GUIMARÃES, Sergio. Aprendendo com a própria história. 3. ed. Rio de Janeiro: Paz e Terra, 2010; HADDAD, Sérgio. O Educador: um perfil de Paulo Freire. São Paulo: Todavia, 2019.; KIRKENDALL,

Andrew. Paulo... Op. cit.

11. FREIRE, Paulo; GUIMARÃES, Sergio. Aprendendo... Op. cit., p. 88; FREIRE,

Paulo. Pedagogia da.

Op. cit., p. 48.

12. FREIRE, Paulo; GUIMARÃES, Sergio. Aprendendo... Op. cit., p. 25

13. FREIRE, Paulo. Soy Proyecto. In: OSORIOVARGAS Jorge (org.). Freire entre nos: a 50 años de Pedagogía del Oprimido. La Serena: Universidad de La Serena, 2018., p. 161

14. FREIRE, Paulo; GUIMARÃES, Sergio. Aprendendo... Op. cit., p. 90.

15. AFFONSO, Almino. Vivemos no Chile o que havíamos amado ter no Brasil, mas não pudemos. In: AUSTIN HENRY, Robert: VASCONCELOS Joana Salém; CANIBILO RAMÍREZ, Viviana (org.). La vía chilena al socialismo 50 años después: historia y memoria. Buenos Aires: Clacso, 2020, p. 545

16. FREIRE, Paulo. Pedagogia da... Op. cit., p. 49-60. conceito de "aderência ao opressor" como um dos mais importantes da obra, iluminando seu poder explicativo da reforma agrária no Chile e levantado a hipótese de coautoria teórica com Maria Edy Ferreira. Por fim, nas considerações finais, argumenta-se que Pedagogia do oprimido é uma obra da práxis coletiva e que, enquanto tal, expõe uma interpretação política sobre a reforma agrária e sistematiza uma "corrente freiriana" que atuou entre as esquerdas latino-americanas na busca por revoluções horizontais.

\section{VIVA O OXIGÊNIO! PAULO FREIRE E A ATMOSFERA CHILENA (1964-1969)}

Quando Paulo Freire pisou nas terras do norte do Chile, em novembro de 1964, estava fugindo de dois golpes militares ocorridos naquele ano: no Brasil e na Bolívia. O segundo golpe pegou Freire de surpresa após cinco dias de exílio

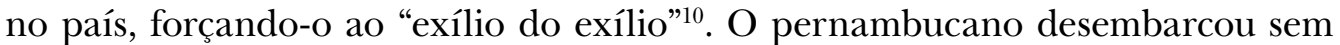
passaporte em Arica, próximo à fronteira com o Peru, graças às articulações dos amigos Plínio de Arruda Sampaio, Paulo de Tarso e Thiago de Mello em Santiago. Ao descer ao nível do mar, depois de duas semanas de angústia e falta de ar na altitude de La Paz, Paulo Freire agradeceu à atmosfera com um desabafo: "viva o oxigênio!"11.

A exclamação era literal, mas com o passar dos anos adquiriu uma dimensão metafórica. O brasileiro se sentia sufocado por dois golpes militares, mas conseguiu respirar na atmosfera do Chile, país que vivenciava reformas estruturais democráticas e uma crescente mobilização popular. "Minha prática de exílio me politizou intensamente. Foi o Chile, inclusive, que fez isso", avaliou Freire em 1986 ${ }^{12}$. Mais tarde, em 1991, Freire agradeceu: "me tornei quase chileno"13. Seu exílio no Chile foi um dos períodos mais produtivos da sua história.

Com a vitória eleitoral de Eduardo Frei em setembro de 1964, o entusiasmo popular reformista estava em pleno impulso. "Comecei a trabalhar imediatamente", lembrou Paulo Freire, "o contexto do exílio até me deu uma possibilidade enorme de aprender mais e de aprofundar as coisas que já vinha fazendo no Brasil" ${ }^{4}$. Almino Affonso, ex-ministro do trabalho de Jango, concordava: "vivemos no Chile o que havíamos amado ter no Brasil, mas não pudemos"15, sintetizou. Mais tarde, relembrando a experiência chilena, Paulo Freire escreveu:

O Chile nos ensinou a América Latina [...]. Percorri grande parte do país em que aprendi realmente muito. Aprendi fazendo parte, ao lado de educadores e educadoras chilenos, de cursos de formação para quem, nas bases, nos assentamentos da reforma agrária, trabalharia com camponeses e camponesas a questão fundamental da leitura da palavra, sempre precedida pela leitura do mundo ${ }^{16}$.

A relação de Paulo Freire com a reforma agrária chilena foi mais orgânica e determinante para Pedagogia do oprimido do que se costuma conhecer. Poucos dias depois de sua entrada no país, o agrônomo Jacques Chonchol, diretor do Indap, contratou Freire para trabalhar na Unidade de Metodologia e Estudos do 
Departamento de Capacitação do instituto. O Indap havia sido criado em 1962 com o objetivo de gerenciar crédito e oferecer assistência técnica a pequenos agricultores, mas, com a direção de Chonchol, o órgão recebeu novas atribuições culturais e educacionais dentro do conceito de promoción popular campesina.

Chonchol recordou: "quando Paulo Freire chegou ao Chile eu não o conhecia, mas estavam aqui dois brasileiros, Plínio Sampaio e Paulo de Tarso, que me apresentaram a ele e disseram 'por que você não o contrata?' Eu o contratei"17. Entre 1964 e 1973, pelo menos dez brasileiros exilados estiveram empregados em instituições da reforma agrária chilena. "A influência intelectual dos brasileiros do exílio foi enorme no debate social e político chileno"18, destacou Marcela Gajardo.

Logo após chegar em Santiago, em um jantar com brasileiros e chilenos, Paulo Freire narrou sua experiência de alfabetização no Nordeste e projetou slides com as pinturas de Francisco Brennand para os círculos de cultura, obras apreendidas pelos militares como "material subversivo". Dois dias depois, Thiago de Mello declamou no telefone ao amigo recém-chegado o poema Canção para os fonemas da alegria, publicado três anos depois como epígrafe de Educação como prática da liberdade (1967). O poema representava mais do que um impulso criativo ou emocionado. Simbolizava, sobretudo, a ponte de acolhimento da comunidade brasileira exilada no Chile para as pedagogias freirianas. A atmosfera chilena de 1964 era pluralista, reformista e democrática.

A multiplicação da pedagogia freiriana no Chile foi rápida. Em 1965 e 1966, foram capacitados 6 mil alfabetizadores com o método psicossocial em cursos intensivos, motivo pelo qual a Unesco, em 1967, premiou o Estado chileno pela promoção de novas metodologias de ensino" ${ }^{19}$. Segundo Zubicueta, "o método era simples, mas implicava a capacitação de milhares de pessoas dispostas a ir aos territórios, conectar-se com as comunidades" ${ }^{20}$.

Quando Freire chegou ao Chile, os debates e lutas sobre a reforma agrária já alcançavam alto grau de maturidade e não demorou muito para a aprovação da Lei $\mathrm{n}^{\circ}$ 16.640, em 28 de julho de 1967, que consolidou a perspectiva estruturalista sobre a mudança do regime de propriedades rurais. Tal perspectiva foi viabilizada pela pressão de lutas camponesas, que deram base popular à aliança entre parlamentares da DC, do Partido Socialista (PS) e do Partido Comunista (PC) para aprovação do projeto, apoiados por economistas, sociólogos e agrônomos da Comissão Econômica para a América Latina e o Caribe (Cepal) e da Food and Agriculture Organization (FAO),cujas sedes se encontram em Santiago.

A lei de reforma agrária definia diferentes critérios de expropriação da terra, entre eles: todos os latifúndios maiores que 80 hectareas de riego básico (HRB); as propriedades "mal exploradas" após três anos de aprovação da lei, independentemente de seu tamanho; as propriedades de pessoas jurídicas, com exceção das cooperativas camponesas; as propriedades subdivididas para driblar a lei; as propriedades com contratos irregulares de arrendamento; aquelas em territórios com obras de irrigação empreendidas pelo Estado, entre outras ${ }^{21}$.

No período de 1967 a 1973, a reforma agrária no Chile foi o processo mais massivo de expropriação de terras por vias legais do mundo ${ }^{22}$. Em apenas
17. Entrevista com Jacques Chonchol realizada pela autora (informação verbal). Santiago, em 14 de abril de 2016.

18. BECA, Carlos Eugenio; RICHARDS, Cecilia; BIANCHETTI, Lucídio. Ernani Maria Fiori: professor brasileiro en tierras chilenas - testemonios. Educação e Realidade, Porto Alegre, v. 38, n. 3, p. 1021 1034, 2013, p. 1024.

19. KIRKENDALL, Andrew. Paulo... Op. cit., p. 74; WILLIAMSON, Guillermo. Paulo... Op. cit., p. 22.

20. ZUBICUETA LUCO Daniela. De imágenes.. Op. cit., p. 73.

21. CHILE. Ley n 16.640. Reforma agraria. Diario Oficial de la Republica de Chile, Santiago, 28 jul. 1967b.

22. BARRACLOUGH Solon; AFFONSO, Almino. Diagnóstico de la reforma agraria chilena. Cuadernos de la Realidad Nacional, Santiago, n. 16, p. 71-123, 1973. 


\section{comunicação \& educação • Ano XXVI • número 2 • jul/dez 2021}

23. CHILE. Leyn ${ }^{\circ} 16.625$. Sindicación Campesina. Diario Oficial de la Republica de Chile, Santiago, 29 abr. 1967a. Sobre a pedagogia freiriana em sindicatos camponeses no Chile ver capítulo 6 de VASCONCELOS, Joana Salém. "O lápis..." Op. cit.

24. GÓMEZ, Sergio. Organización campesina en Chile: reflexiones sobre su debilidad actual. Revista Austral de Ciencias Sociales Valdivia, n. 6, p. 3-18, 2002 HUERTA, Maria Antonieta. Otro agro para Chile: historia de la reforma agraria en el proceso social y político. Santiago: CESOC, 1989

25. CARABANTES Waldemar Cortés. Formas muertas y dinámicas en nuestra educación de adultos. Revista de Educación Santiago, n. 93, 1963.

26. Entrevistas com Marcela Gajardo realizada pela autora (informação verbal), Santiago, em 4 de dezembro de 2018; e com entrevista Jacques Chonchol realizada pela autora (informação verbal), Santiago, em 26 de novembro de 2018 . cinco anos, o setor reformado da agricultura se expandiu de 1,9\% a $35 \%$ da superfície agrícola, enquanto os latifúndios foram reduzidos de 55,3\% para 2,9\%. Somente enquanto Paulo Freire esteve no Chile, foram expropriados 2,8 milhões de hectares de terra fértil, entregues a assentamentos camponeses, dentro dos quais a Cora atuava com programas pedagógicos freirianos.

O território expropriado pela reforma agrária se tornou um território pedagógico para o método psicossocial, mas não só. Fora da área reformada, a pedagogia freiriana foi adotada por confederações sindicais camponesas, por trabalhadores rurais em latifúndios ainda não expropriados e por comitês de pequenos agricultores. Entre 1967 e 1969, mais de 225 mil camponeses passaram a integrar sindicatos comunais seguindo a lei de sindicalização camponesa e frequentar cursos inspirados em Freire ${ }^{23}$. Em 1973, mais de 310 mil camponeses estavam sindicalizados ${ }^{24}$. Por meio da educação democrática, a pedagogia freiriana catalisava a ruptura com hierarquias tradicionais, sugeria caminhos práticos para autogestão camponesa e métodos para construir o poder popular.

A reforma agrária definia a "capacitação camponesa" como um processo educacional em três frentes: alfabetização, formação sindical e técnica produtiva. A capacitação foi considerada a base para a nova economia camponesa, fundamentada na autogestão e no cooperativismo. Em 1963, o analfabetismo rural entre adultos chegava a $59 \%$, um obstáculo para a reforma agrária e a autodeterminação camponesa ${ }^{25}$. $\mathrm{O}$ assentamento era uma forma de propriedade transitória, que deveria durar de 3 a 5 anos, até que seus membros optassem pelo parcelamento da terra em lotes familiares ou pela formalização de uma cooperativa. Esse período transitório era a janela para a capacitação camponesa, quando os cursos oferecidos ao campesinato foram veículos de inúmeras disputas políticas. Nesse contexto, o fato de Paulo Freire estar proibido de exercer atividade partidária não o impediu de formar uma posição sobre as tensões latentes.

Como consultor da Unesco, Freire estava formalmente alocado no Ministério da Agricultura, mas circulou por diferentes instituições, construindo uma massiva rede de adesão no Ministério da Educação ${ }^{26}$. A capacidade de Freire de circular por diferentes corredores do governo e influenciar setores políticos diversos (às vezes rivais) sinalizava o peso e a multiplicidade da sua influência. Ao potencializar saberes camponeses e fomentar um novo poder de organização política (sindicatos) e produtiva (assentamentos), a Pedagogia do oprimido participava do acirramento da luta de classes no seio da reforma agrária.

\section{PAULO FREIRE LÊ A REFORMA AGRÁRIA NO CHILE}

No Chile, Paulo Freire escreveu muitos textos vinculados a sua práxis. Entre os mais conhecidos estão Educação como prática da liberdade (1967) e Pedagogia do oprimido (1968). Outra publicação importante foi ¿Extensión o comunicación? (1969), na qual expressou divergências com extensionistas rurais e técnicos agrícolas que inferiorizavam os saberes camponeses na educação produtiva e praticavam o que Freire chamou de "invasão cultural”, uma prática 
característica de capacitadores "alienados da própria ignorância”. Além desses, Freire redigiu pelo menos doze textos mimeografados (relatórios para Unesco, orientações para círculos de cultura, debates com educadores, sugestões metodológicas e reflexões sobre a reforma agrária chilena), oito dos quais nunca foram publicados no Brasil ${ }^{27}$.

Pedagogia do oprimido estava lastreada em uma práxis política sobre a reforma agrária no Chile que, por um lado, lançava luz sobre as contradições da "aderência ao opressor", mas, por outro, apontava o protagonismo camponês como único caminho possível de mudança orgânica. Freire defendia a autodeterminação da subjetividade camponesa na criação de uma nova estrutura produtiva. Por essa leitura, Pedagogia do oprimido estava em uma disputa crítica com as correntes "economicistas" e "produtivistas" das esquerdas latino-americanas, sobretudo os partidos comunistas, o que se tornou mais evidente durante o governo de Salvador Allende.

Em Pedagogia da esperança, Paulo Freire lembrou de suas incursões ao mundo camponês: "viajando quase todo o país, acompanhado sempre por jovens chilenos, na sua maioria progressistas, ouvi camponeses e discuti com eles sobre aspectos de sua realidade", narrou. "Debati com agrônomos e técnicos agrícolas uma compreensão político-pedagógica democrática de sua prática; debati problemas gerais da política educacional com os educadores" ${ }^{28}$.

Impedido de atuar na esfera político-partidária, Freire levou muito a sério sua distância de qualquer ativismo político formal no país e evitou tratar de suas divergências em público: "Isso aprendi com Lênin", disse duas décadas depois, "Lênin sempre respeitou o país em que esteve exilado" ${ }^{29}$. Mas conforme o brasileiro se tornava importante e influente no Chile, atuando no seio de um processo reformista cada vez mais tenso e polarizado, parecia quase inevitável que expressasse, na natureza do seu próprio trabalho, uma concepção e uma posição a respeito da reforma agrária.

A leitura que Paulo Freire fazia da reforma agrária chilena era autoral e nada unânime, consequentemente encontrou entusiastas e críticos. Se houve alguma batalha visível travada pelo brasileiro no Chile, no corpo a corpo do processo educacional da reforma agrária, ela ocorreu junto aos setores do funcionalismo estatal, que se impacientavam com o tempo pedagógico do seu método e reivindicavam a primazia do aumento da produtividade acima das peculiaridades subjetivas do campesinato. "O aumento da produção no processo de reforma agrária é eminentemente cultural. $\mathrm{O}$ aumento indispensável da produção não pode ser visto como algo separado do universo cultural em que ocorre", insistiu o educador ${ }^{30}$.

No debate sobre o tempo pedagógico e a pressa em aumentar a produtividade, Freire se posicionava a favor do ritmo da subjetividade camponesa, alegando que qualquer atropelo para ganhar tempo seria, ao contrário, uma perda de tempo: "tanto a técnica, como o procedimento empírico do camponês, são manifestações culturais e [...] não podem ser mecanicamente substituídos [...]. [Alguns técnicos] terminam por cair nessa irônica contradição: 'para não perder tempo',
27. Esse corpus disperso e fragmentado, que intitulei "escritos chilenos", foi reagrupado na tese: VASCONCELOS, Joana Salém. "O lápis..." Op. cit. Os textos são: La concepción "bancaria" de la educación y la deshumanización: la concepción problematizadora de la educación y la humanización (1967); Alfabetización funcional en Chile: informe Unesco (1968); Algunas sugerencias en torno de una labor educativa que vea el asentamiento como una totalidad (1968); Plan de Trabajo para el año (1968); La alfabetización de adultos: crítica de su visión ingenua: comprensión de su visión crítica (1968); Los campesinos también pueden ser los autores de sus propios textos de lectura (1968); Investigación y metodología de la investigación del "tema generador": reducción y codificación temáticas (1968); A propósito del tema generador y del universo temático (1968); Formación pedagógica de los padres (1968); Al coordinador de un círculo de cultura (1968); El rol del trabajador social en el proceso de cambio (1968); El compromiso del profesional con la sociedad (1968); ¿Extensión o comunicación? (1969); ¿Una dimensión política de la educación? Una conversación con Paulo Freire (1972); e Sugerencias para la aplicación del método en terreno (1968), de Paulo Freire e Raul Velozo.

28. FREIRE, Paulo. Pedagogia da... Op. cit., p. 57.

29. FREIRE; Paulo; GUIMARÃES, Sergio. Aprendendo... Op. cit., p. 105.

30. FREIRE, Paulo. Alfabetización Funcional en Chile: informe. Santiago: ICIRA, 1968a. Mimeografado. 
31. Idem. El compromiso del profesional con la sociedad. In: FREIRE, Paulo. Educação e conscientização. Cuernacava: Centro Intercultural de Documentación, 1968c. Mimeografado.

32. Idem. ¿Extensión.. Op. cit., p. 33.

33. Idem. Pedagogia do... Op. cit., p. 167.

34. Idem. ¿Extensión.. Op. cit., p. 37-383.

35. A investigação temática do assentamento de Buin está descrita em: FREIRE, Paulo. Pedagogia do.. Op. cit., p. 133-166.

36. Idem. Alfabetización.. Op. cit., p. 2. o que fazem é perdê-lo"31, criticou Freire em 1968. No debate com a tecnocracia agrícola chilena, o brasileiro desenvolveu alguns dos conceitos mais importantes da sua filosofia educacional, como "invasão cultural", "alienação da ignorância", "cultura do silêncio" e "ação antidialógica"32. O quarto e último capítulo de Pedagogia do oprimido, trata justamente da teoria da ação antidialógica, elaborada a partir de seus embates pedagógicos na reforma agrária chilena ${ }^{33}$.

"Os camponeses não rechaçam o diálogo porque sejam ontologicamente avessos a ele. Existem razões de ordem histórico-sociológica, cultural e estrutural, que explicam sua negativa ao diálogo", alertava Freire em 1969, "sua experiência existencial se constitui nos marcos do antidiálogo. O latifúndio, como estrutura vertical e fechada é, em si mesmo, antidiálogo [...]. Não será com antidiálogo que romperemos o silêncio camponês, mas com diálogo que problematize o silêncio e suas causas" ${ }^{34}$. Se o latifúndio era a forma econômica do antidiálogo, a paciência pedagógica perante situações de silêncio camponês seria uma condição necessária para abertura disruptiva, porém lenta, à sua condição de sujeito protagonista da reforma agrária.

A principal estratégia freiriana para romper o silêncio camponês eram os círculos sobre o conceito antropológico de cultura, vistos como "perda de tempo" por alguns técnicos chilenos. $\mathrm{O}$ conceito antropológico de cultura era a primeira etapa do processo de alfabetização por conscientização e foi um recurso da investigação temática e da ação cultural ${ }^{55}$. Por meio do diálogo sobre imagens que correlacionavam natureza, trabalho e sociedade, o coordenador do círculo sobre conceito antropológico de cultura tinha como objetivo desconstruir o mito de que os analfabetos fossem pessoas incultas ou ignorantes. Com isso, dilatava-se a compreensão dos camponeses analfabetos sobre sua condição de sujeito produtor de cultura, material e imaterial. O diálogo sobre o conceito antropológico de cultura proporcionava uma mudança conscientizadora de mão dupla: ao mesmo tempo que se desativava a cultura do silêncio camponês, demonstrando a riqueza da sua propulsão subjetiva, se combatia a alienação da ignorância dos "invasores culturais", que deveriam relativizar seu próprio saber perante os outros saberes do analfabeto camponês.

Nesse sentido, o processo pedagógico necessário à reforma agrária, tal como proposto por Freire, implicava uma crítica da visão tecnicista da transformação estrutural na agricultura e um embate com setores produtivistas impacientes. Em relatório para Unesco, após três anos de contrato, o brasileiro alertou:

Mecanicismo, tecnicismo, economicismo são dimensões de uma mesma visão acrítica e antidialética do processo de reforma agrária, implicando a minimização do homem, que se torna mero objeto da mudança. O equívoco fundamental dessa visão acrítica ou a percepção distorcida do processo é que se pretende operar no domínio histórico-cultural, especificamente humano, no qual se dá a reforma agrária, como quem se comporta no domínio das coisas ${ }^{36}$.

Freire lia a reforma agrária como um processo de transformação econômico-cultural, pois as relações de trabalho e as técnicas de produção se assentavam sobre condições existenciais e culturais. Quando os camponeses eram relutantes a novas técnicas de produção e novas formas de organizações do 


\section{Pedagogia do oprimido \\ - Joana Salém Vasconcelos}

trabalho (mais cooperativas e menos hierárquicas, por exemplo), isso decorria de uma objeção subjetiva que não seria alterada sem um trabalho consciente de ação cultural. Em outras palavras, a transformação estrutural da técnica, da propriedade e do trabalho não ocorreria mecanicamente, porque a cultura era substância estruturante da economia, tanto quanto a economia era estruturante da cultura. Mas sua visão dialética da transformação estrutural estava na contramão das epistemologias dominantes, impregnadas de economicismo.

Frequentemente, Freire se defendeu de críticas a respeito de seu "culturalismo" e "idealismo" - inclusive vindas de setores marxistas ${ }^{37}$. Mas seu olhar dialético sobre os nexos entre economia e cultura era capaz de explicar, tal como escreveu em seu relatório para Unesco, as causas da

manutenção de grande parte das manifestações culturais características da estrutura latifundiária, na estrutura transitória do assentamento. Só um mecanicista não consegue entender que a superestrutura não se transforma automaticamente com a mudança da infraestrutura ${ }^{38}$.

Outro texto fundamental na práxis freiriana da reforma agrária no Chile tratava do assentamento como uma totalidade econômica-cultural, cuja transformação produtiva precisava estar acompanhada da apropriação das ferramentas democráticas de autogestão e poder popular camponês ${ }^{39}$. Na leitura freiriana da reforma agrária, era prioritário fortalecer o camponês como sujeito indispensável da estruturação autônoma dos assentamentos e das novas relações de propriedade e trabalho. Em razão das nuances do processo político chileno, Freire se tornou um incômodo para ala direita da DC, alinhada com Eduardo Frei, até o fim do contrato do brasileiro, que não foi renovado, em fins de 1968.

\section{VOZES CAMPONESAS EM PEDAGOGIA DO OPRIMIDO}

Em Pedagogia do oprimido, as vozes do campesinato chileno aparecem em quinze passagens ${ }^{40}$. Já a investigação temática realizada no assentamento El Recurso, em Buin, a 40 quilômetros ao sul de Santiago, coordenada pela socióloga Maria Edy Ferreira no Icira, é a matéria-prima de 33 páginas do terceiro capítulo, na seção intitulada "A investigação temática dos temas geradores e sua metodologia"41. Os participantes dessa experiência registraram os resultados em dois relatórios, que serviram de fontes para Freire escrever o livro. Tais relatórios contêm os únicos registros de círculos de cultura gravados e transcritos em sua totalidade, permitindo que o método dialógico das equipes freirianas no Chile seja revisitado de maneira integral ${ }^{42}$. As transcrições completas das falas camponesas nos círculos de cultura de 1968 e 1969 revelavam a importância da escuta no método das equipes freirianas, realizada com dois objetivos práticos: multiplicar o diálogo horizontal entre os próprios camponeses, permitindo que trabalhadores de assentamentos e territórios distantes escutassem uns aos outros e criassem identidades comuns; e permitir que pesquisadores do Icira estudassem a subjetividade camponesa como centro do protagonismo político.
37. Idem. ¿Una dimensión política de la educación? Una conversación con Paulo Freire. Cuadernos de Educación, Santiago, v. 4, n. 2, p. 2-25, 1972.

38. Idem. Alfabetización. Op. cit., p. 5.

39. Idem. Algunas sugerencias de una labor educativa que vea el asentamiento como una totalidade. Santiago: Icira, 1968b.

40. Idem. Pedagogia do. Op. cit., p. 44, 45, 67, 69, 70, 71, 99, 143, 150, 153, 154, $155,157,159,238$

41. Ibidem, p. 133-166.

42. A análise historiográfica desses materiais inéditos foi realizada pioneiramente na pesquisa de VASCONCELOS, Joana Salém. "O lápis..." Op. cit. Os relatórios com as vozes camponesas são: FERREIRA, Maria Edy; FIORI, José Luis. Investigación temática cultural de los campesinos de El Recurso. Santiago: Icira, 1969. Mimeografado; INSTITUTO PARA CAPACITAÇÃO E INVES TIGAÇÃO DA REFORMA AGRÁRIA. Investigación temática: Asentamiento El Recurso. São Paulo: Centro de Referência do Instituto Paulo Freie, 1968. 303 p. Caixa FPF-ACP-01. 


\section{comunicação \& educação • Ano XXVI • número 2 • jul/dez 2021}

Textualmente, em Pedagogia do oprimido, as vozes camponesas aparecem como rastros não ordenados e assistemáticos, em notas, discurso indireto e na forma de anedotas. Se por um lado Freire pretendia transformar a escuta do outro (camponês) em um método de pesquisa sobre sua subjetividade, também é evidente que o fez de maneira desorganizada e assistemática, tornando opaca a historicidade da teoria. Portanto, compreender a historicidade do texto demanda o conjunto de "paratextos" (os escritos chilenos de Freire) e a compreensão do contexto (por meio da historiografia da reforma agrária).

Vejamos alguns destes rastros. Na nota 22, Freire reproduz as palavras de um camponês que teria dito: "o camponês, que é um dependente, começa a ter ânimo para superar sua dependência quando se dá conta da sua dependência. Antes disso, segue o patrão e diz quase sempre: 'Que posso fazer, se sou um camponês?"' 43 Por que Freire deu voz a esse camponês? Possivelmente, porque ele revelava autoconsciência a respeito da transitividade de sua consciência, bem como a dificuldade em superar a "aderência ao opressor". Freire não escondia seu entusiasmo quando as palavras dos camponeses traziam os elementos vitais da sua teoria. Na nota 26, registrou a voz de outro trabalhador rural: "o camponês se sente inferior ao patrão porque lhe parece como o que tem mérito de saber e dirigir" ${ }^{4}$. Assim, identifica-se, na prática, os sentimentos fundamentais da aderência ao opressor.

Na nota 28, Freire prossegue com seus exemplos: "Por que o senhor (disse certa vez um camponês participante de um círculo de cultura ao educador) não explica primeiramente os quadros (referia-se às codificações)? Assim (concluiu) nos custará menos e não nos dói a cabeça" ${ }^{\prime 5}$. Os diálogos entre Freire, educadores e camponeses mostram o doloroso processo de romper com a cultura do silêncio e assumir as responsabilidades da luta. Esse processo é caracterizado em Pedagogia do oprimido como a necessidade de se romper com a autodesvalia, um neologismo de Freire que mistura nitidamente o português com o espanhol. "A autodesvalia é outra característica dos oprimidos", escreveu Freire:

Resulta da introjeção que fazem eles da visão que deles têm os opressores. De tanto ouvirem de si mesmos que são incapazes, que não sabem nada, que não podem saber, que são enfermos, indolentes, que não produzem em virtude de tudo isso, terminam por se convencer da sua "incapacidade" [...]. Não são poucos os camponeses que conhecemos em nossa experiência educativa que, após alguns momentos de discussão viva em torno de um tema que lhes é problemático, param de repente e dizem ao educador: "Desculpe, nós devíamos estar calados e o senhor falando. O senhor é o que sabe; nós, os que não sabemos". Muitas vezes insistem que nenhuma diferença existe entre eles e o animal. "É mais livre do que nós", dizem ${ }^{46}$.

43. FREIRE, Paulo. Pedagogia do... Op. cit., p. 67.

44. Ibidem, p. 69.

45. Ibidem, p. 69.

46. Ibidem, p. 69-70, grifo nosso.
Em Pedagogia da esperança, Freire relata uma interessante tarde de diálogo com camponeses de um assentamento que visitou com Júlio Salgado, supervisor educacional da Cora. Freire permaneceu em silêncio no círculo coordenado por Salgado, até que resolveu se manifestar. Depois de sua fala, o silêncio se instaurou, até ser quebrado por um camponês, que expressou sentir intimidação e vergonha: eles deveriam estar calados e Freire deveria falar. Como resposta, 


\section{Pedagogia do oprimido \\ - Joana Salém Vasconcelos}

Freire fez um jogo de perguntas, em que os camponeses demonstraram que ele nada sabia sobre produção agrícola e condições climáticas, tornando evidente que os camponeses sabiam muitas coisas que o "mestre" ignorava ${ }^{47}$.

O processo de superação da autodesvalia dos camponeses chilenos está diretamente relatado em Pedagogia do oprimido pela voz de um camponês que declarou: "Diziam que não produzíamos porque éramos borrachos, preguiçosos. Tudo mentira. Agora estamos sendo respeitados como homens, vamos mostrar a todos que nunca fomos borrachos, nem preguiçosos. Éramos explorados, isso sim" ${ }^{\text {" }}$.

Baseado nessas experiências, o brasileiro concluiu: "é preciso que comecem a ver exemplos da vulnerabilidade do opressor para que, em si, vá operando-se convicção oposta à anterior. Enquanto isso não se verifica, continuarão abatidos, medrosos, esmagados"49. A expropriação dos latifúndios retirava o poder dos patrões e impulsionava uma reviravolta subjetiva do oprimido, fortalecendo a luta social pela terra. Na nota 29, Freire lembra que um trabalhador rural certa vez lhe disse: "o camponês tem um medo quase instintivo do patrão" ${ }^{50}$. Na nota 32 , ele registra a fala de um camponês sobre o sofrimento do oprimido, que se convertia em violência machista e alcoolismo: "O camponês é um dependente. Não pode expressar o seu querer. Antes de descobrir sua dependência, sofre. Desabafa sua 'pena' em casa, onde grita com os filhos, bate, desespera-se. Reclama da mulher", dizia o trabalhador, "Não desabafa sua 'pena' com o patrão porque considera um ser superior. Em muitos casos, o camponês desabafa sua 'pena' bebendo" 51 .

Freire era atento à filosofia popular e ao pensamento profundo dos analfabetos. Em uma das passagens de Pedagogia do oprimido em que se nota o aprendizado do próprio método com os camponeses chilenos, o brasileiro relata:

Certa vez, num dos círculos de cultura do trabalho que se realiza no Chile, um camponês a quem a concepção bancária classificaria de "ignorante absoluto", declarou, enquanto discutia, através de uma "codificação" o conceito antropológico de cultura: "descubro agora que não há mundo sem homem". E quando o educador lhe disse: "Admitamos, absurdamente, que todos os homens do mundo morressem, mas ficasse a terra, ficasse as árvores, os pássaros, os animais, os rios, o mar, as estrelas, não seria isso o mundo?". "Não!", respondeu enfático, "faltaria quem dissesse: isto é o mundo". $\mathrm{O}$ camponês quis dizer exatamente que faltaria a consciência do mundo que, necessariamente, implica o mundo da consciência ${ }^{52}$.

Na nota 80, Freire pontua que as codificações de seu método não dependem de imagens e poderiam ser verbais: "consistem nesse caso na apresentação, em poucas palavras, que fazem os investigadores, de um problema existencial e a que se segue sua 'descodificação'. A equipe do Indap, no Chile, vem usando-os com resultados positivos em investigações temáticas” ${ }^{\text {53. }}$. Em cerca de três páginas do livro, Freire relata em detalhes uma inovação do método proposta pelo jovem chileno Gabriel Bode, "que há mais de dois anos trabalha com o método na etapa de pós-alfabetização, trouxe uma contribuição da mais alta importância” ${ }^{4}$.

Baseado em situações que vivenciou com camponeses que precisavam fundar um sindicato, Freire criticava: "imaginemos agora um educador que organizasse o seu programa 'educativo' para estes homens e, em lugar da discussão desta
47. Idem. Pedagogia da.. Op. cit., p. 63-64, 66-67.

48. Idem. Pedagogia do. Op. cit., p. 70.

49. Ibidem, p. 70.

50. Ibidem, p. 70

51. Ibidem, p. 71.

52. Ibidem, p. 99, grifo nosso.

53. Ibidem, p. 150.

54. O "grande achado de Gabriel Bode", nos dizeres de Freire, foi a "experimentar a projeção simultânea de situações" como forma de potencializar a capacidade analítica relacional dos camponeses sobre duas experiências existenciais concomitantes e indiretamente relacionadas. Ibidem, p. 153-155. 
55. Ibidem, p. 159, grifo do autor.

56. Ibidem, p. 238.

57. FERREIRA, Maria Edy. Expectativas campesinas y asignación de tierras de Culiprán. Santiago: Icira, 1968. Mimeografado.

58. Idem. Tendencias del poder entre los campesinos asentados. Santiago: Icira, 1970. Mimeografado.

59. Anterior inclusive à formulação de Raymond Williams sobre a "estrutura de sentimento", conceito que se adaptaria perfeitamente ao trabalho de Ferreira. WILLIAMS, Raymond. Marxismo e literatura. Rio de Janeiro: Zahar, 1979.

60. Aliás, mesmo as esquerdas chilenas da Unidade Popular entre 1970 e 1973, se tivessem lido os trabaIhos de Maria Edy Ferreira, não teriam demorado tanto tempo a perceber as contradições da reforma agrária que ela apontava desde 1965. temática, lhes propusessem a leitura de textos que, certamente, chamaria de 'sadios' e nos quais se fala, angelicalmente, de que 'a asa é da ave" ${ }^{\text {"55. }}$.

A possibilidade de escutar os camponeses chilenos em um contexto de reforma agrária, com a quebra de hierarquias de propriedade e poder, a ruptura com as formas tradicionais de obediência e a criação de novas formas de autodeterminação, foi para Freire uma oportunidade insubstituível para a redação de Pedagogia do oprimido. Para ele, a fonte de aprendizado das vanguardas da transformação democrática só poderia ser a subjetividade pulsante dos verdadeiros protagonistas: os oprimidos. O campesinato nunca seria mobilizado com palavras de ordem que provinham de fora da sua realidade: "quando a tentativa de união dos camponeses se faz à base de práticas ativistas, que giram em torno de slogans [...], o que se pode observar é a justaposição dos indivíduos, que dá à sua ação um caráter puramente mecanicista" ${ }^{\text {6 }}$, conclui Freire.

\section{5. "ADERÊNCIA AO OPRESSOR" E A REFORMA AGRÁRIA NO CHILE}

Existem evidências históricas suficientes para afirmar que os conceitos fundamentais de Pedagogia do oprimido, como "aderência ao opressor", "cultura do silêncio" e a oposição entre ação dialógica e antidialógica, são fundamentos teóricos resultantes do diálogo de Freire com as equipes chilenas, que contribuíram decisivamente para a produção do livro, mas que são subestimadas ao se desprezar a historicidade da teoria.

Há indícios de que a socióloga Maria Edy Ferreira, por exemplo, foi uma aliada crucial de Freire na criação do conceito de "aderência ao opressor". Trabalhando no Icira, Ferreira realizou duas pesquisas empíricas em assentamentos, que subsidiaram os debates de Freire com as equipes no Indap e no Icira. Na primeira, ela investigou as aspirações dos camponeses assentados em Culiprán e suas expectativas sobre a propriedade individual ou coletiva após o assentamento ${ }^{57}$. Na segunda, pesquisou as tendências de poder hierárquico no interior de 80 assentamentos espalhados pelo Vale Central, nos quais foram entrevistados $3.164 \operatorname{assentados}^{58}$. Eram estudos pioneiros sobre subjetividades camponesas, formados por um material empírico original de largo escopo, cuja análise propunha um enfoque dialético entre "expectativas", "aspirações" camponesas e transformação econômica até então inexistente nas pesquisas mais importantes sobre a reforma agrária da época, que privilegiavam a perspectiva estruturalista, deixando pouco espaço para a subjetividade camponesa ${ }^{59}$. Em volumosas entrevistas, Ferreira escutou as falas camponesas sobre perspectivas de futuro e alimentou uma metodologia freiriana de pesquisa sociológica. Explicava, assim, os mecanismos por meio dos quais as hierarquias do antigo latifúndio se reproduziam subjetivamente na nova estrutura do assentamento, fundamentando empiricamente a "aderência ao opressor" de Pedagogia do oprimido com uma amplitude concreta que o próprio Freire não havia feito ${ }^{60}$. 
Entre as descobertas de Ferreira, estava a explicação subjetiva sobre porque muitos camponeses identificavam a pequena propriedade individual com a plena liberdade e o verdadeiro fim do patrão, ao mesmo tempo que identificavam o funcionário da Cora ou o Estado como o "novo patrão" no assentamento. Durante décadas, os camponeses lutaram para ampliar sua produção autônoma no interior do latifúndio, o que gerava a tendência de continuar buscando uma meta individual no interior dos assentamentos. Concomitantemente, segundo Ferreira, as antigas hierarquias patronais se refletiam na "formação de uma oligarquia burocrática constituída por dirigentes camponeses reeleitos para cargos de autoridade dentro do assentamento" ${ }^{61}$. Ferreira argumentava que os desejos e aspirações dos camponeses não apareciam na forma de "plano ordenado", como requerido pela Cora, e se perguntava: "frente aos projetos da Cora e planos de governo, como o camponês assentado vai construindo as linhas de seu próprio projeto? São orientações convergentes?" $62 \mathrm{Ou}$ ainda, como construir uma democracia produtiva no seio de uma subjetividade marcada pela autoridade patronal?

Em Pedagogia do oprimido, ao definir a aderência ao opressor, Freire certamente teoriza com base nas pesquisas empíricas de Ferreira, com quem mantinha uma forte amizade e cumplicidade no trabalho. Ele sintetiza:

em certo momento da sua experiência existencial, os oprimidos assumem uma postura que chamamos de "aderência" ao opressor [...]. Por exemplo, querem a reforma agrária não para se libertarem, mas para passarem a ter terra e, com esta, tornar-se proprietários ou, mais precisamente, patrões de novos empregados ${ }^{63}$.

E prossegue:

Poder-se-á dizer - e com razão - que isto se deve ao fato de que a situação concreta, vigente, de opressão, não foi transformada. E que, nessa hipótese, o capataz, para assegurar seu posto, tem de encarnar, com mais dureza ainda, a dureza do patrão. Tal afirmação não nega a nossa - a de que, nestas circunstâncias, os oprimidos têm no opressor o seu testemunho de "homem". Até as revoluções, que transformam a situação concreta de opressão em uma nova, em que a libertação se instaura como processo, enfrentam esta manifestação da consciência oprimida. Muitos dos oprimidos que, direta ou indiretamente, participaram da revolução, marcados pelos velhos mitos da estrutura anterior, pretendem fazer da revolução a sua revolução privada ${ }^{64}$.

A aderência ao opressor também foi percebida pelos próprios camponeses que lutavam pelo sucesso das formas coletivas de propriedade e enxergavam nos amarillos (camponeses apatronados) e nos defensores exclusivos da parcela individual, entraves das velhas hierarquias e aspirações que bloqueavam a construção de uma nova agricultura comunitária. Diante desse fenômeno, as esquerdas divergiam sobre os ritmos da mudança. Enquanto vanguardas minoritárias do PS defendiam a necessidade da coletivização estatal da terra, desconsiderando as subjetividades heterogêneas dos camponeses sobre a propriedade individual, outros setores das esquerdas, especialmente aqueles que trabalharam com Freire e atuavam no Mapu, propunham que a cooperativa mista poderia conciliar os

61. FERREIRA, Maria Edy. Tendencias... Op. cit. p. 22

62. FERREIRA, Maria Edy. Expectativas... Op. cit, p. 16.

63. FREIRE, Paulo. Pedagogia do... Op. cit., p. 44

64. Ibidem, p. 45. 


\section{comunicação \& educação • Ano XXVI • número 2 • jul/dez 2021}

desejos individuais com as vantagens da produção coletiva, respeitando os ritmos da subjetividade camponesa na mudança social no campo ${ }^{65}$. Enfim, é certo que as equipes freirianas, apesar de pequenas e com ação limitada, compartilharam uma estratégia dialógica e horizontal da ação cultural para a reforma agrária, cuja práxis foi impulsionada pela presença de Freire e reciprocamente alimentou a teorização de Pedagogia do oprimido, afinidade que se estendeu para além da estadia do autor no Chile.

\section{CONSIDERAÇÕES FINAIS}

A atuação de Paulo Freire em diferentes instituições públicas chilenas engendrou uma forte influência da sua pedagogia em programas educacionais do Estado, especialmente no seio da reforma agrária. Freire foi transformado pela realidade chilena e pelo diálogo com os camponeses, produzindo um corpus documental de "escritos chilenos" que servem de paratexto a Pedagogia do oprimido. Tais escritos foram utilizados como fontes para análise da historicidade da obra. À luz da historiografia da reforma agrária no Chile e dos "escritos chilenos", é possível visualizar o livro Pedagogia do oprimido como um documento histórico da práxis freiriana na reforma agrária chilena. Freire fez da escuta dialógica um método de pesquisa, tornando a subjetividade camponesa a matéria-prima de sua teoria. Nesse sentido, a escrita dessa obra só foi possível devido ao método psicossocial aplicado em larga escala no Chile, alfabetizando quase meio milhão de pessoas, majoritariamente camponeses, entre 1965 e 1970. A ação cultural para a reforma agrária foi institucionalizada e dinamizou as transformações no campo de maneira imensurável ${ }^{66}$. As equipes freirianas trouxeram novas possibilidades ao método freiriano durante e depois da estadia de Freire.

Pedagogia do oprimido, nesse contexto, foi o registro de uma experiência, um documento sobre os desafios da reforma agrária chilena, cuja amplitude teórica permitiu ao livro alçar voos que o próprio Freire não imaginava. A pedagogia freiriana expressa na obra representa uma concepção e uma estratégia específicas para a reforma agrária chilena, atuando na transformação cultural como um enlace dialético da transformação econômica. Em outras palavras,

65. VASCONCELOS, Joana Salém. Dilemas agrários da Unidade Popular: conflitos rurais na via chilena ao socialismo (1967-1973). In: COSTA, Adriane Vidal; BORGES, Elisa Campos (org.). Os 50 anos da Unidade Popular no Chile: um balanço historiográfico. Belo Horizonte: Fino Traço, 2020a. p. 223-268.

66. FREIRE, Paulo. Ação cultural para liberdade e outros escritos. 5. ed. Rio de Janeiro: Paz e Terra, 1981. por priorizar a conformação dos sujeitos populares do campo, Freire propunha combater ao mesmo tempo a "invasão cultural", a "alienação da ignorância" e a "aderência ao opressor", o que colocava os chilenos freirianos em uma posição muito particular no cenário das disputas políticas.

As perspectivas mecanicistas ou produtivistas sobre a reforma agrária foram criticadas por Freire e suas equipes. Ao mesmo tempo, a proposta pedagógica freiriana para reforma agrária, se levada às últimas consequências, poderia gerar uma quebra das hierarquias mais profunda e revolucionária do que aquela que a ala direita da DC pretendia. Sua pedagogia concatenava uma estratégia de consolidação do sujeito popular camponês e do seu poder popular autônomo, 
o que, dependendo da correlação de forças, incomodava as vanguardas dirigentes. Por fim, é possível afirmar que as equipes freirianas foram coautoras práticas de Pedagogia do oprimido, formando uma "corrente freiriana" de disputa da reforma agrária chilena: invisível, pluripartidária, constituída por educadores e ativistas que priorizavam a radicalidade lenta do diálogo com as bases e evitavam as disputas sectárias e velozes das vanguardas.

\section{REFERÊNCIAS BIBLIOGRÁFICAS}

AFFONSO, Almino. Vivemos no Chile o que havíamos amado ter no Brasil, mas não pudemos. In: AUSTIN HENRY, Robert; VASCONCELOS, Joana Salém; CANIBILO RAMÍREZ, Viviana (org.). La vía chilena al socialismo 50 años después: historia y memoria. Buenos Aires: CLACSO, 2020. t. 2. Disponível em: http:/ /biblioteca.clacso.edu.ar/clacso/se/20201201032252/La-via-chilena-alsocialismo-Tomo-II.pdf. Acesso em: 19 nov. 2021.

ARAVENA ALVARADO, Rodrigo; DÍAZ-DIEGO, José. Paulo Freire en Chile (1964-1969): testimonios de exdirigentes campesinos durante la reforma agraria. Informes Fondo de Apoyo a la Investigación Patrimonial, Santiago, n. 18, p. 91-118, 2016.

AUSTIN, Robert (org.). Diálogos sobre Estado y educación popular en Chile: de Frei a Frei (1964-1993). Santiago: CECATP, 2004.

AUSTIN, Robert. State, literacy \& popular education in Chile: 1964-1990. Lanham: Lexington Books, 2003.

BARRACLOUGH, Solon; AFFONSO, Almino. Diagnóstico de la reforma agraria chilena. Cuadernos de la Realidad Nacional, Santiago, n. 16, p. 71-123, 1973.

BECA, Carlos Eugenio; RICHARDS, Cecilia; BIANCHETTI, Lucídio. Ernani Maria Fiori: professor brasileiro en tierras chilenas - testemonios. Educação e Realidade, Porto Alegre, v. 38, n. 3, p. 1021-1034, 2013.

CARABANTES, Waldemar Cortés. Formas muertas y dinámicas en nuestra educación de adultos. Revista de Educación, Santiago de Chile, n. 93, 1963.

CHILE. Ley $\mathrm{n}^{\circ}$ 16.640. Reforma agraria. Diario Oficial de la Republica de Chile, Santiago, 28 jul. 1967b.

CHILE. Ley $\mathrm{n}^{\circ}$ 16.625. Sindicación Campesina. Diario Oficial de la Republica de Chile, Santiago, 29 abr. 1967a.

FERNÁNDEZ, José Antonio. La construcción de un pensamiento inacabado. Cuadernos de Pedagogía, Santiago, n. 265, p. 61-65, 1998.

FERREIRA, Maria Edy. Expectativas campesinas y asignación de tierras de Culiprán. Santiago: Icira, 1968. Mimeografado. 
comunicação \& educação • Ano XXVI • número 2 • jul/dez 2021

FERREIRA, Maria Edy. Tendencias del poder entre los campesinos asentados. Santiago: Icira, 1970. Mimeografado.

FERREIRA, Maria Edy; FIORI, José Luis. Investigación temática cultural de los campesinos de El Recurso. Santiago: Icira, 1969. Mimeografado.

FREIRE, Paulo. ¿Extensión o comunicación? Santiago: Icira, 1969.

FREIRE, Paulo. ¿Una dimensión política de la educación? Una conversación con Paulo Freire. Cuadernos de Educación, Santiago, v. 4, n. 2, p. 2-25, 1972.

FREIRE, Paulo. Ação cultural para liberdade e outros escritos. 5. ed. Rio de Janeiro: Paz e Terra, 1981.

FREIRE, Paulo. Alfabetización funcional en Chile: informe. Santiago: Icira, 1968a. Mimeografado.

FREIRE, Paulo. Algunas sugerencias en torno de una labor educativa que vea el asentamiento como una totalidad. Santiago: Icira, 1968b. Mimeografado.

FREIRE, Paulo. Educação como prática da liberdade. Rio de Janeiro: Paz e Terra, 1967a.

FREIRE, Paulo. El compromiso del profesional con la sociedad. In: FREIRE, Paulo. Educação e conscientização. Cuernavaca: Centro Intercultural de Documentación, 1968c.

FREIRE, Paulo. Pedagogia da esperança. 17. ed. Rio de Janeiro: Paz e Terra, 2011.

FREIRE, Paulo. Pedagogia do oprimido. 65. ed. Rio de Janeiro: Paz e Terra, 2018.

FREIRE, Paulo; GUIMARÃES, Sergio. Aprendendo com a própria história. 3. ed. Rio de Janeiro: Paz e Terra, 2010.

GAJARDO, Marcela. Paulo Freire: crónica de sus años en Chile. Santiago: FLACSO Chile, 2019.

GÓMEZ, Sergio. Organización campesina en Chile: reflexiones sobre su debilidad actual. Revista Austral de Ciencias Sociales, Valdivia, n. 6, p. 3-18, 2002.

HADDAD, Sérgio. O Educador: um perfil de Paulo Freire. São Paulo: Todavia, 2019.

HOLST, John D. Paulo Freire in Chile, 1964-1969: "Pedagogy of the oppressed" in its sociopolitical economic context. Harvard Educational Review, Cambridge, v. 76, n. 2, p. 243-270, 2006.

HUERTA, Maria Antonieta. Otro agro para Chile: historia de la reforma agraria en el proceso social y político. Santiago: CESOC, 1989.

INSTITUTO PARA CAPACITAÇÃO E INVESTIGAÇÃO DA REFORMA AGRÁRIA. Investigación temática: asentamiento "El Recurso". São Paulo: Centro de Referência do Instituto Paulo Freire, 1968. 303 p., Caixa FPF-ACP-01. 
KIRKENDALL, Andrew. Paulo Freire and the Cold War politics of literacy. Chapel Hill: University of North Carolina, 2010.

OSORIO VARGAS, Jorge (org.). Freire entre nos: a 50 años de Pedagogía del Oprimido. La Serena: Universidad de La Serena, 2018.

VASCONCELOS, Joana Salém. “O lápis é mais pesado que a enxada”: reforma agrária no Chile e pedagogias camponesas para transformação econômica (1955-1973). 2020. Tese (Doutorado em História Econômica) - Universidade de São Paulo, São Paulo, 2020b.

VASCONCELOS, Joana Salém. Dilemas agrários da Unidade Popular: conflitos rurais na via chilena ao socialismo (1967-1973). In: COSTA, Adriane Vidal; BORGES, Elisa de Campos (org.). Os 50 anos da Unidade Popular no Chile: um balanço historiográfico. Belo Horizonte: Fino Traço, 2020a. p. 223-268.

WILLIAMS, Raymond. Marxismo e literatura. Rio de Janeiro: Zahar, 1979.

WILLIAMSON, Guillermo. Paulo Freire (1965-1969): su paso por Chile y el Chile por que pasó. Santiago: [S. n.], 1989. Mimeografado.

ZUBICUETA LUCO, Daniela. De imágenes, palabras y diálogos: alfabetización freiriana y concientización campesina durante la reforma agraria en Chile (1965-1973). 2018. Tesis (Magíster en Historia) - Universidad de Santiago de Chile, Santiago, 2018. 